\title{
Karakteristik Morfologi Famili Arcidae di Perairan yang Berbeda (Karangantu dan Labuan, Banten)
}

\section{Characteristics Morphologically of Family Arcidae in Different Coastal Waters (Karangantu and Labuan, Banten)}

\author{
Oto Prasadi'), Isdradjad Setyobudiandi'), Nurlisa A. Butet"1) dan Sri Nuryati²) \\ ${ }^{1)}$ Departemen Manajemen Sumberdaya Perairan, FPIK-IPB, Bogor \\ ${ }^{2)}$ Departemen Budidaya Perairan, FPIK-IPB, Bogor \\ Sekolah Pascasarjana, P.S. Pengelolaan Sumberdaya Perairan, IPB, Bogor \\ E-mail: oto.prasadi@gmail.com
}

Diterima : 28 September 2015; Diperiksa : 12 Oktober 2015; Revisi : 04 Desember 2015; $\quad$ Disetujui :18 Desember 2015

\begin{abstract}
Bivalves are marine organisms inhabiting aquatic substrates. As a cosmopolit an sedentary organism, they are vulnerable to environmental changes. There are varieties of bivalves in habit Indonesian coastal waters. Distribution points and fishing grounds in Indonesia are Karangantu and Labuan, Banten Province. Bivalve dominating the areas is Family Arcidae. Different characteristics of environmental condition will be affect morphologically each species. This research was aimed to identifying morphologically in Famliy Arcidae in Karangantu and Labuan coastal waters. Research method applied was comparative descriptive using survey technique. Two stations were each selected from Karangantu and Labuan. 25 individuals from each stations. There were two dominant spesies in Karangantu, i.e., Anadara granosa and Anadara antiquata, while in Labuan, there were three dominant species, i.e., Anadara granosa, Anadara scapha and Barbatia barbata. Generally, potential of bivalves in Banten Province, i.e., A. granosa with size bigger shell in Labuan coastal waters.
\end{abstract}

Keywords: Family arcidae, meristik bivalve, mophologically of bivalves and morfometri

\begin{abstract}
ABSTRAK
Kekerangan adalah organisme laut yang kosmopolit, mendiami substrat perairan dan bersifat sedenter (bivalvia) sehingga organisme tersebut sangat rentan terpengaruh oleh perubahan lingkungan. Di Perairan Indonesia terdapat beberapa jenis kekerangan. Salah satunya pusat penyebaran dan penangkapan kekerangan di Indonesia adalah Perairan Karangantu dan Labuan, Provinsi Banten. Jenis kekerangan yang dominan di perairan tersebut adalah famili Arcidae. Kondisi lingkungan perairan yang berbeda akan mempengaruhi morfologi dari setiap spesies kekerangan. Penelitian ini bertujuan untuk mengidentifikasi morfologi pada famili Arcidae di Perairan Karangantu dan Labuan. Metode penelitian yang digunakan adalah deskriptif komparatif dengan teknik survei. Lokasi penelitian yang dipilih yaitu Perairan Karangantu dan Labuan, masing-masing dua stasiun. Setiap stasiun memiliki karakteristik kondisi lingkungan yang berbeda, seperti daerah Muara Sungai dan daerah industri. Sampel kerang diambil dengan metode sapuan menggunakan alat tangkap kerang (garuk). Sampel dari setiap spesies ditangkap sebanyak 25 individu/stasiun. Setiap spesies memiliki karakteristik morfologi yang berbeda, walaupun beberapa individu memiliki kesamaan ciri morfologi antara satu stasiun dengan stasiun lainnya. Potensi sumberdaya kekerangan di Perairan Karangantu yaitu $A$. granosa dan $A$. antiquata, sedangkan di Perairan Labuan yaitu $A$. granosa, $A$. scapha dan B. barbata. Secara umum potensi sumberdaya kekerangan di provinsi banten yaitu $A$. granosa dengan ukuran cangkang terbesar di Perairan Labuan.
\end{abstract}

Kata Kunci: Famili arcidae, meristik kerang, morfologi kerang dan morfometri

\section{PENDAHULUAN}

\subsection{Latar Belakang}

Shellfish (kekerangan) merupakan salah satu organisme laut yang rentan terpengaruh oleh perubahan lingkungan, karena pergerakannya yang bersifat pasif atau bersifat sedenter. Setiap spesies dari kekerangan memiliki tingkat toleransi terhadap perubahan lingkungan yang berbeda-beda. Salah satunya yaitu kekerangan dari famili Arcidae. Arcidae merupakan bivalvia yang bersifat filter feeder yang mendiami perairan intertidal dengan substrat lumpur berpasir pada kedalaman air antara dua sampai $20 \mathrm{~m}$. Bivalvia memiliki peran ekologis dalam siklus rantai makanan, mempengaruhi struktur komunitas makrozoobentos dan sebagai bioindikator ${ }^{(1)}$. 
Arcidae terdiri dari sembilan genus yaitu Arca, Anadara, Bathyarca, Barbatia, Cucullaea, Litharca, Noetia, Senilia dan Trisidos. Arcidae banyak dimanfaatkan secara komersial oleh masyarakat sekitar, karena bernilai ekonomi dan merupakan salah satu sumber protein hewani diantaranya adalah kerang darah dan kerang bulu ${ }^{(2)}$. Permintaan yang terus meningkat menyebabkan kerang ini menjadi salah satu target utama dalam penangkapan. Hal ini menyebabkan harga kerang darah (Anadara granosa Linnaeus, 1758) dan kerang bulu (Anadara antiquata Linnaeus, 1758) relatif lebih tinggi dibandingkan jenis kerang lainnya seperti kerang gelatik (Anadara scapha Linnaeus, 1758) dan kerang mencos (Barbatia barbata Linnaeus, 1758) di daerah perairan sekitar Teluk Banten dan Teluk Lada.

Penyebaran kekerangan secara geografis meliputi Red Sea, New Caledonia, China, Jepang, Vietnam, Thailand, Filipina, Laut China Selatan, Indonesia, Perairan Pasifik bagian Barat, dan Australia ${ }^{(3)}$. Penyebaran hewan di Perairan Indonesia meliputi Pesisir Sumatera bagian Barat, Selat Malaka, Pantai Utara Jawa, Pantai Timur Jawa, Bali, Nusa Tenggara, Kalimantan, Sulawesi Selatan, Sulawesi Utara, Maluku, dan Papua ${ }^{(4)}$. Perairan Karangantu yang merupakan bagian dari Teluk Banten dan Labuan bagian dari Teluk Lada merupakan daerah yang potensial bagi perkembangan hidup kekerangan dari famili Arcidae. Kekerangan dari famili Arcidae di Karangantu maupun Labuan berperan dalam memenuhi kebutuhan sumberdaya kekerangan di Provinsi Banten, sehingga potensinya perlu ditingkatkan.

Teluk Banten secara geografis berada di Kabupaten Serang, merupakan perairan semi tertutup yang menghadap Pantai Utara Jawa dengan luas sekitar $120 \mathrm{~km}^{2}$ dengan kedalaman tidak lebih dari $25 \mathrm{~m}$ dan memiliki dasar perairan yang terdiri atas lumpur bercampur pasir pada bagian pesisirnya ${ }^{(5)}$. Kegiatan industri yang ada di sekitar perairan diantarannya pabrik plastik, industri perakitan kapal, industri kerajinan, dan kegiatan antropogenik lainnya. Teluk Lada secara geografis berada di Kabupaten Pandeglang, merupakan perairan pesisir yang menghadap ke arah atau merupakan bagian dari Selat Sunda. Selat ini merupakan selat yang dinamis, karena massa air Laut Jawa bercampur dengan massa air yang berasal dari Samudera Hindia $^{(6)}$. Kegiatan antropogenik di sekitar perairan tersebut diantaranya Pembangkit Listrik Tenaga Uap (PLTU), perkebunan kelapa, dan pemukiman warga yang dapat berdampak negatif. Salah satu dampak negatif dari kegiatankegiatan tersebut akan mengakibatkan tekanan terhadapat perkembangan dan pertumbuhan secara morfologi dari organisme akuatik, khususnya yang bersifat sedenter.

Morfologi merupakan ilmu yang mengkaji tentang bentuk tubuh atau bagian tubuh suatu makhluk hidup. Pemilihan ciri-ciri morfologi menggunakan metode morfometri yaitu ukuran atau perbandingan ukuran tubuh bagian luar antara satu bagian dengan bagian lainnya ${ }^{(7)}$. Pemilihan ciri-ciri morfologi untuk usaha pelestarian suatu spesies saat ini belum banyak dilakukan. Hal ini dikarenakan pengujiannya masih terbatas dan belum banyak diketahui. Studi morfologi perlu dilakukan, karena dapat dijadikan dasar pengetahuan untuk mengetahui karakteristik dari suatu populasi. Oleh karena itu, perlu dilakukan identifikasi sebagai informasi awal. Data mengenai morfologi di suatu perairan seperti morfometri dan meristik perlu diketahui sebagai langkah awal untuk tahap pelestarian selanjutnya.

\subsection{Tujuan}

Tujuan penelitian ini adalah untuk mengetahui perbedaan morfologi pada famili Arcidae di perairan Karangantu dan Labuan dan hasil dari penelitian ini diharapkan dapat memberikan informasi ilmiah mengenai perbedaan morfologi dan diharapkan menjadi acuan dalam menjaga kelestarian kekerangan di perairan Karangantu dan Labuan.

\section{BAHAN DAN METODE}

\subsection{Tempat dan Waktu Penelitian}

Penelitian ini dilaksanakan pada bulan Februari-April 2015. Lokasi penelitian di Perairan Karangantu yang berada di Teluk Banten dan Perairan Labuan yang berada di Teluk Lada, seperti yang disajikan pada Gambar 1. Setiap perairan memiliki karakteristik kondisi lingkungan yang berbeda-beda, seperti kualitas air, substrat dan kegiatan industri di sekitar perairan. Stasiun 1 dipengaruhi oleh aktivitas antropogenik disekitar Muara Sungai Karangantu, stasiun 2 oleh kegiatan industri, stasiun 3 oleh kegiatan PLTU dan stasiun 4 oleh aktivitas antropogenik di sekitar Muara Sungai Bama. Stasiun 1 dan 2 berada di Perairan Karangantu dan stasiun 3 dan 4 berada di Perairan Labuan. Kegiatan industri dan antropogenik di sekitar Perairan Karangantu yaitu pabrik plastik, industri perakitan kapal, industri kerajinan dan Muara Sungai Karangantu. Di Perairan Labuan terdapat Pembangkit Listrik Tenaga Uap (PLTU), perkebunan kelapa dan Muara Sungai Bama. Metode penelitian yang digunakan dalam penelitian ini adalah deskriptif komparatif dengan teknik survei, teknik pengambilan sampel dilakukan berdasarkan pertimbangan tertentu (purposive sampling). Identifikasi dan analisis di lakukan di 
Laboratorium Produktivitas dan Lingkungan Perairan (Proling/MSP) dan Laboratorium Biologi Makro (BIMA/MSP). Tabel 1 menunjukkan koordinat lokasi pengambilan sampel di dua perairan.

Tabel 1. Koordinat lokasi pengambilan sampel

\begin{tabular}{|c|c|c|}
\hline Lokasi Sampling & Stasiun Sampling & Koordinat \\
\hline \multirow{2}{*}{$\begin{array}{l}\text { Perairan } \\
\text { Karangantu }\end{array}$} & Stasiun 1 (Muara) & $\begin{array}{l}6^{0} 01^{\prime} 02.1 " \mathrm{~S} ; \\
106^{0} 09^{\prime} 56.8^{\prime \prime} \mathrm{E}\end{array}$ \\
\hline & Stasiun 2 (Industri) & $\begin{array}{l}6^{0} 00^{\prime} 23.9^{\prime \prime} \mathrm{S} ; \\
106^{0} 08^{\prime} 12.5^{\prime \prime} \mathrm{E}\end{array}$ \\
\hline \multirow{2}{*}{ Perairan Labuan } & Stasiun 3 (PLTU) & $\begin{array}{l}6^{0} 24^{\prime} 04.3^{\prime \prime} \mathrm{S} ; \\
105^{0} 48^{\prime} 44.5^{\prime \prime} \mathrm{E}\end{array}$ \\
\hline & Stasiun 4 (Muara) & $\begin{array}{l}6^{0} 26^{\prime} 05.8 \text { " S; } \\
105^{0} 48^{\prime} 39.0 \text { " E }\end{array}$ \\
\hline
\end{tabular}

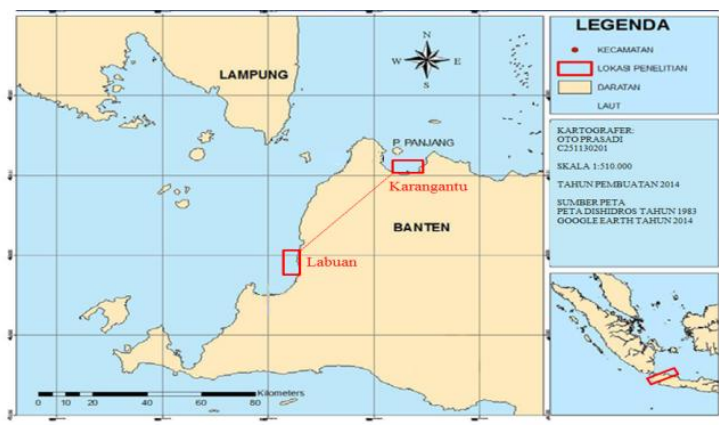

Gambar 1. Lokasi pengambilan sampel

\subsection{Alat dan Bahan}

Alat yang digunakan selama penelitian adalah alat tangkap kerang (garuk), alat bedah, termometer, kertas $\mathrm{pH}$ universal, hand refraktosalinometer, jangka sorong, timbangan digital, botol sampel, coolbox, kertas milimeter blok, plastik dan buku identifikasi kerang. Bahan yang digunakan selama penelitian adalah spesies kerang.

\subsection{Pengambilan Sampel Kerang}

Sampel kerang diambil pada setiap stasiun pengamatan dengan metode sapuan (Swept Area) menggunakan alat tangkap kerang (garuk). Sampel dari setiap spesies ditangkap sebanyak 25 individu/stasiun (total 100 individu/spesies). Sampel yang didapat kemudian disortir, dibersihkan untuk dilakukan identifikasi dan analisis berdasarkan kebutuhan. Semua spesies kerang dimasukan dalam kantong plastik serta diberi label, kemudian disimpan dalam coolbox untuk diidentifikasi lanjut. Hasil yang diperoleh dicocokkan dengan mengacu pada buku Compendium of Seashells ${ }^{(8)}$.

\subsection{Pengambilan Sampel Air}

Pengambilan dan pengukuran kualitas perairan meliputi parameter fisika (suhu, salinitas, kedalaman dan substrat) dan kimia $(\mathrm{pH}$ dan klorin) dari setiap stasiun dilakukan secara insitu (suhu, salinitas, $\mathrm{pH}$ dan kedalaman) dan secara exsitu (klorin dan substrat) dengan mengacu kepada metode baku APHA $2012^{(9)}$.

\subsection{Karakteristik Morfologi}

Karakteristik morfologi yang diukur pada kekerangan dari famili Arcidae berupa karakter morfometri dan meristik yang meliputi panjang cangkang $(\mathrm{P})$, tinggi cangkang $(\mathrm{T})$, lebar cangkang $(\mathrm{L})$, panjang ligamen $(\mathrm{PL})$, tinggi umbo (TU), simetri kanan (SA), simetri kiri (SI), berat total (BT) dan berat daging (BD). Setiap karakteristik morfologi dari setiap individu (kecuali panjang cangkang), akan dirasiokan terhadap panjang cangkang $(P)$, sehingga dapat menghindari diferensiasi yang berkaitan dengan struktur umur pada setiap sampel. Rasio karakteristik morfologi ini kemudian dianalisis untuk mengetahui rasio mana yang dapat digunakan sebagai penciri utama setiap spesies famili Arcidae dari setiap stasiun. Gambar 2 menunjukkan karakteristik morfologi kerang yang diukur menggunakan jangka sorong dengan ketelitian $0,01 \mathrm{~mm}$ dan timbangan digital dengan ketelitian 0,01 gram.

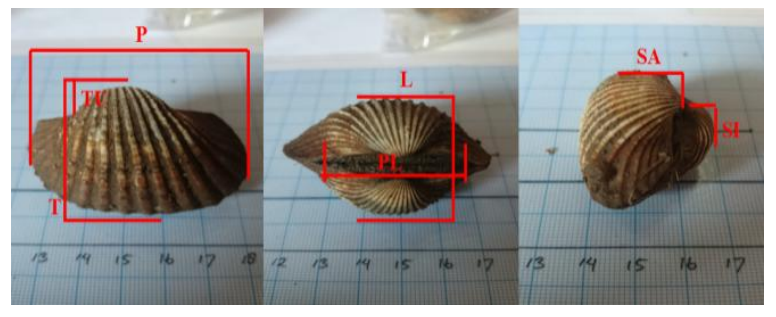

Gambar 2. Karakteristik morfologi kerang (Dokumentasi pribadi)

Analisis diskriminan dilakukan untuk mengelompokkan data berdasarkan variabelvariabel kuantitatif. Analisis ini dilakukan untuk mengetahui pengelompokkan antara spesies atau untuk mendeskripsikan pola pusat sebaran. Analisis diskriminan menggunakan delapan variabel morfologi dari famili Arcidae yang berperan sebagai variabel independen secara bersama-sama (simultan) yang mampu dengan baik membedakan dan memprediksi pola keanekaragaman morfologi dan populasi dari Famili Arcidae yang didapat di Perairan Karangantu dan Labuan. Analisis diskriminan dilakukan berdasarkan metode stepwise menggunakan software SPSS Versi 17 dan Microsoft Excell for windows.

\subsection{Analisis Hubungan Panjang Bobot}

Analisis hubungan panjang bobot dilakukan untuk mengetahui hubungan panjang bobot dari setiap spesies kekerangan. Perhitungan pola pertumbuhan yang dilakukan pada setiap spesies dari famili Arcidae hanya pada spesies dengan jumlah penangkapan yang memenuhi target dari 
masing-masing lokasi perairan (dapat mewakili). Model hubungan panjang bobot mengikuti pola hukum kubik dari dua parameter yang dianalisis. Asumsi hukum kubik ini adalah bahwa idealnya setiap pertambahan panjang akan menyebabkan pertambahan berat, sehingga untuk menganalisis hubungan panjang bobot setiap spesies dari Famili Arcidae yang tertangkap menggunakan pendugaan sebagai berikut ${ }^{(10)}$ :

$$
\mathrm{W}=a L^{b}
$$

W adalah bobot total $(\mathrm{g}), \mathrm{L}$ adalah panjang cangkang $(\mathrm{mm})$, a adalah intersep, dan $\mathrm{b}$ adalah penduga pola pertumbuhan (koefisien regresi) setiap spesies kerang yang tertangkap.

Korelasi parameter dari hubungan panjangbobot dapat dilihat dari nilai konstanta $b$, yaitu:

Nilai $b=3$, menunjukkan pola pertumbuhan isometrik

Nilai $b \neq 3$, menunjukkan pola pertumbuhan allometrik:

Jika $b>3$, pola pertumbuhan allometrik positif (pertumbuhan berat dominan)

Jika $b<3$, pola pertumbuhan allometrik negatif (pertumbuhan panjang dominan).

Kemudian dilakukan uji t untuk lebih menguatkan pengujian hipotesis berdasarkan ${ }^{(11)}$ dengan rumus sebagai berikut:

$$
t_{\text {hit }}=\frac{b_{1}-b_{0}}{S b_{1}}
$$

Keterangan:

$$
\mathrm{Sb}_{1}=\text { Simpangan baku } \mathrm{b}_{1}
$$

$\mathrm{b}_{0}=$ Intercept

$b_{1}=$ Slope

dengan hipotesis:

$\mathrm{H}_{0}: \mathrm{b}=3$ (isometrik)

$\mathrm{H}_{1}: \mathrm{b} \neq 3$ (allometrik)

Nilai $t_{\text {hitung }}$ akan dibandingkan dengan nilai $t_{\text {tabel }}$ sehingga keputusan yang akan diambil adalah sebagai berikut:

$t_{\text {hitung }}>t_{\text {tabel }}$, maka Tolak $\mathrm{H}_{0}$

$\mathrm{t}_{\text {hitung }}<\mathrm{t}_{\text {tabel }}$, maka Gagal Tolak $\mathrm{H}_{0}$, Terima $\mathrm{H}_{1}$

Keeratan hubungan panjang-bobot spesies kekerangan dari famili Arcidae ditunjukkan oleh nilai koefisien korelasi ( $r$ ). Nilai $r$ yang mendekati satu $(r>0,7)$ menggambarkan hubungan yang erat antar keduanya, sedangkan nilai $r$ yang mendekati nol atau menjauhi satu $(r<0,7)$ menggambarkan hubungan yang tidak erat antar keduanya ${ }^{(11)}$.

\section{HASIL DAN PEMBAHASAN}

\subsection{Analisis Diskriminan}

Spesies kerang yang tertangkap di Perairan Karangantu dan Perairan Labuan sebanyak empat spesies (Anadara granosa, Anadara antiquata, Anadara scapha dan Barbatia barbata) dengan jumlah tangkapan yang berbeda-beda. Potensi sumberdaya kekerangan dari setiap lokasi perairan dapat dilihat dari jumlah tangkapan yaitu 25 individu/stasiun. Potensi sumberdaya kekerangan di Perairan Karangantu terdiri dari dua spesies yaitu $A$. granosa dan $A$. antiquata, sedangkan di Perairan Labuan terdiri dari tiga spesies yaitu $A$. granosa, $A$. scapha dan $B$. barbata. Tabel 2 menunjukkan perbandingan nilai statistik panjang cangkang kerang dari dua perairan berbeda.

Tabel 2. Perbandingan nilai statistik panjang cangkang kerang di Karangantu dan Labuan

\begin{tabular}{l|l|l|l|l}
\hline Spesies & Stasiun & Min & Max & $\mathrm{N}$ \\
\hline \multirow{2}{*}{ A. granosa } & $\mathrm{KA}$ & 23.94 & 38.11 & 50 \\
\cline { 2 - 5 } & $\mathrm{L}$ & 24.45 & 58.29 & 50 \\
\hline \multirow{2}{*}{ A. scapha } & $\mathrm{KA}$ & 27.93 & 32.73 & 2 \\
\cline { 2 - 5 } & $\mathrm{L}$ & 17.87 & 29.87 & 50 \\
\hline \multirow{2}{*}{ B. barbata } & $\mathrm{KA}$ & 38.69 & 42.31 & 7 \\
\cline { 2 - 5 } & $\mathrm{L}$ & 31.22 & 44 & 50 \\
\hline \multirow{2}{*}{ A. antiquata } & $\mathrm{KA}$ & 16.26 & 54.56 & 50 \\
\cline { 2 - 5 } & $\mathrm{L}$ & 24.45 & 41 & 16 \\
\hline
\end{tabular}

Spesies yang tertangkap dari dua lokasi yaitu Perairan Karangantu dan Perairan Labuan memiliki jumlah tangkapan yang berbeda-beda setiap spesiesnya. Dilihat dari jumlah dan ukuran tangkapan kerang, spesies yang memenuhi target penangkapan yaitu 50 individu/spesies dari setiap lokasi penangkapan, hanya spesies $A$. granosa yang jumlah tangkapannya memenuhi target. Menunjukkan bahwa $A$. granosa memiliki potensi sumberdaya kekerangan di Provinsi Banten dan Perairan Labuan memiliki ukuran cangkang terbesar dari spesies $A$. granosa.

Berdasarkan hasil perhitungan delapan karakter morfologi, nilai rasio yang dihasilkan dapat dijadikan sebagai penciri utama untuk melihat sebaran dari setiap spesies. Di Perairan Karangantu koordinat $A$. granosa stasiun satu ($0,662)$ stasiun dua $(0,662) \quad n=7 \quad$ individu mendekati stasiun satu dan $\mathrm{n}=6$ individu mendekati stasiun dua. Koordinat $A$. antiquata stasiun satu $(-0,854)$ stasiun dua $(0,854) n=6$ individu mendekati stasiun satu dan $\mathrm{n}=5$ individu mendekati stasiun dua, sedangkan di Perairan Labuan Koordinat $A$. granosa stasiun tiga ($0,521)$ stasiun $4(0,521) n=6$ individu mendekati stasiun tiga dan $\mathrm{n}=9$ individu mendekati stasiun empat. Koordinat $A$. scapha stasiun tiga $(1,109)$ stasiun empat $(-1,109) \mathrm{n}=3$ individu mendekati stasiun tiga dan $n=5$ individu mendekati stasiun 
empat. Koordinat $B$. barbata stasiun tiga $(-0,474)$ stasiun empat $(0,474) \mathrm{n}=9$ individu mendekati stasiun tiga dan $n=7$ individu yang mendekati stasiun empat. Adanya kesamaan ciri morfologi antara satu individu dengan individu lainnya pada masing-masing spesies, menandakan adanya hubungan antara lokasi satu dengan lokasi lainnya. Gambar 3 menunjukkan sebaran spesies kerang dari setiap stasiun yang di gambarkan dalam grafik fungsi diskriminan.

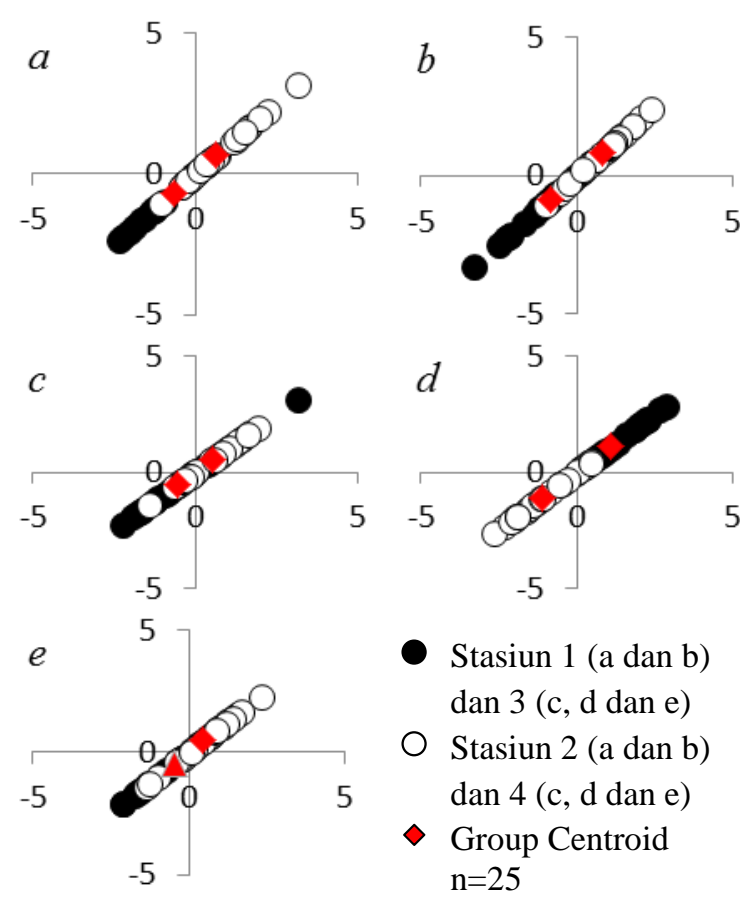

Gambar 3. Grafik fungsi diskriminan karakteristik morfologi kerang a. A. granosa, b. A. antiquata di Karangantu dan c. $A$. granosa, d. A. scapha, e. B. barbata di Labuan.

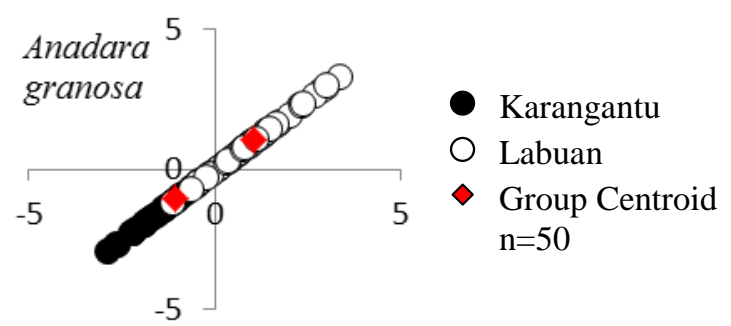

Gambar 4. Grafik fungsi diskriminan karakteristik morfologi spesies kerang di Karangantu dan Labuan.

Spesies kekerangan yang tertangkap dari dua lokasi yaitu Perairan Karangantu dan Perairan Labuan, dilihat dari jumlah tangkapan kerang yang memenuhi target 50 individu/lokasi yaitu $A$. granosa, sehingga spesies ini dapat digunakan untuk mengetahui sebaran $A$. granosa dari setiap lokasi, untuk mengetahui hubungan setiap lokasi dilihat dari kesamaan ciri morfologi. Koordinat $A$. granosa di Perairan Karangantu $(-1,038)$ dan Perairan Labuan $(1,038) \quad n=9$ individu yang mendekati Perairan Karangantu dan $n=8$ individu yang mendekati Perairan Labuan. Gambar 4 menunjukkan sebaran $A$. granosa di Karangantu dan Labuan yang di gambarkan dalam grafik fungsi diskriminan.

\subsection{Perhitungan Panjang Bobot}

Perhitungan hubungan panjang bobot pada $A$. granosa, dikarenakan spesies ini jumlah tangkapannya memenuhi target, sehingga dapat dilakukan perhitungan hubungan panjang bobot untuk mengetahui perbandingan antara $A$. granosa di Karangantu dan Labuan. Gambar 5 menunjukkan hubungan panjang bobot $A$. granosa di Karangantu dan Labuan yang di gambarkan dalam grafik.
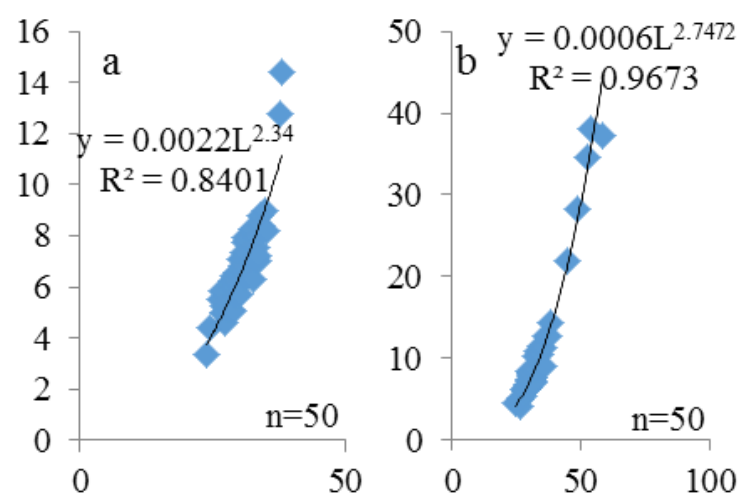

Gambar 5. Hubungan panjang bobot spesies kerang $A$. granosa, (a) Karangantu dan (b) Labuan.

\subsection{Analisis Kualitas Perairan}

Nilai kualitas air yang didapat pada 4 stasiun memiliki nilai yang berbeda pada parameter salinitas, kedalaman dan substrat, sesuai dengan karakteristik di setiap stasiun dan perbedaan di setiap lokasi yaitu substrat, di Perairan Karangantu substrat dominan debu lumpur berpasir, sedangkan di Perairan Labuan substrat dominan debu pasir berlumpur.

\subsection{Korelasi Morfologi Kerang dan Perairan}

Status biota di perairan dipengaruhi oleh fluktuasi lingkungan perairan di habitatnya. Perubahan kondisi lingkungan di suatu perairan akan mempengaruhi pertumbuhan dan perkembangan organisme tertentu. Semua spesies kerang dari famili Arcidae yang tertangkap dari dua lokasi yaitu Perairan Karangantu dan Labuan sebanyak empat spesies yaitu $A$. granosa, $A$. scapha, $B$. barbata dan $A$. antiquata. Potensi sumberdaya kekerangan di Perairan Karangantu terdiri dari $A$. granosa dan $A$. antiquata, sedangkan di Perairan 
Labuan terdiri dari A. granosa, A. scapha dan B. barbata. Setiap spesies memiliki karakteristik morfologi yang berbeda-beda, seperti $A$. granosa (cangkang kasar dan besar membulat dan tidak berambut), $A$. scapha (cangkang halus dan kecil membulat dan berambut tipis), $B$. barbata (cangkang halus dan kecil memanjang dan berambut) dan $A$. antiquata (cangkang halus dan besar membulat dan berambut tebal). Perbedaan morfologi tersebut akan mempengaruhi kelangsungan hidup suatu organisme. Spesies kerang yang tertangkap, yang ukuran cangkangnya besar adalah kerang darah dan kerang bulu. Kerang darah dan kerang bulu setelah dipanen masih bisa hidup beberapa hari walaupun tanpa air, berbeda dengan kerang gelatik dan kerang mencos yang lebih rentan mati. Oleh sebab itu, tidak mengherankan jika pedagang menjual kerang dalam keadaan hidup dengan ciri cangkang tertutup rapat bila terkena sentuhan, sedangkan kerang yang mati cangkangnya agak terbuka ${ }^{(12)}$.

Dilihat dari jumlah dan ukuran tangkapan kerang, spesies yang berpotensi dari dua perairan (jumlah penangkapan memenuhi target), hanya spesies $A$. granosa. Spesies $A$. granosa memiliki potensi sumberdaya kekerangan di Provinsi Banten dan Perairan Labuan (Teluk Lada) merupakan perairan penghasil ukuran cangkang kerang terbesar dari spesies $A$. granosa dengan rataan ukuran panjang cangkang $3.279 \mathrm{~cm}$ dan bobot total $10.188 \mathrm{gram}$, sedangkan Perairan Karangantu (Teluk Banten) panjang cangkang $3,053 \mathrm{~cm}$ dan bobot total 6.784 gram. Menurut ${ }^{(13)}$, rataan ukuran cangkang dan bobot total kerang darah Bojonegara (Teluk Banten) lebih besar $3,211 \mathrm{~cm}$ dan 12,251 gram dari 351 individu dibandingkan kerang darah Panimbang (Teluk Lada) 2,493 cm dan 6,827 gram dari 162 individu. Adanya perbedaan jumlah penangkapan individu/lokasi dan lamanya sampling menyebabkan beberapa perbedaan. Keragaman morfologi tersebut dapat disebabkan oleh dua faktor, yaitu plastisitas fenotip dan keragaman genetik. Perubahan ukuran cangkang kerang dari besar menjadi kecil maupun kecil menjadi besar dapat disebabkan oleh adanya tekanan baik dari kegiatan industri maupun Pembangkit Listrik Tenaga Uap (PLTU) yang dioperasikan secara resmi sejak tahun 2009. Kerang darah masih tetap dapat bertahan hidup di daerah yang terkontaminasi bahan pencemar dengan mengembangkan plastisitas fenotip, cangkang yang tebal merupakan salah satu indikator pertahanan diri terhadap tekanan lingkungan ${ }^{(13)}$.

Spesies yang tertangkap dari setiap stasiun dilakukan analisis diskriminan untuk mengetahui pengelompokkan atau pusat sebaran antara spesies berdasarkan stasiun penangkapan maupun antara lokasi penangkapan. Spesies kekerangan di Perairan Karangantu terdapat lima sampai tujuh individu yang memiliki kesamaan ciri morfologi antara stasiun satu dan stasiun dua, sedangkan spesies kekerangan di Perairan Labuan terdapat lima sampai sembilan individu yang memiliki kesamaan ciri morfologi antara stasiun tiga dan stasiun empat, sedangkan spesies A. granosa di Perairan Karangantu terdapat sembilan individu yang memiliki kesamaan ciri morfologi dengan Perairan Labuan dan delapan individu yang memiliki kesamaan dengan Perairan Karangantu. Kesamaan ciri morfologi baik dari setiap stasiun maupun setiap lokasi perairan menandakan adanya hubungan setiap lokasi dengan lokasi lainnya. Kerang darah Bojonegara (Teluk Banten) dan Panimbang (Teluk Lada) berasal dari sumber genetik yang sama ${ }^{(13)}$.

Perhitungan panjang bobot pada $A$. granosa dari dua perairan nilai koefisiennya memiliki hubungan korelasi yang sangat erat, hal ini terlihat dari nilai korelasi yang mendekati satu dan memiliki pola pertumbuhan allometrik negatif, dimana pertumbuhan panjang cangkang lebih cepat dibandingkan dengan bobot totalnya. $\mathrm{Hal}$ ini sesuai dengan pendapat ${ }^{(14)}$, menyatakan bahwa apabila nilai koefisien korelasi 0,90-1,00 menunjukkan korelasi yang sangat kuat. Menurut (15), perbedaan nilai $b$ juga dapat disebabkan oleh perbedaan jumlah dan variasi biota yang diamati. Gambrar 6 menunjukkan empat spesies kerang yang tertangkap di Perairan Karangantu dan Perairan Labuan.

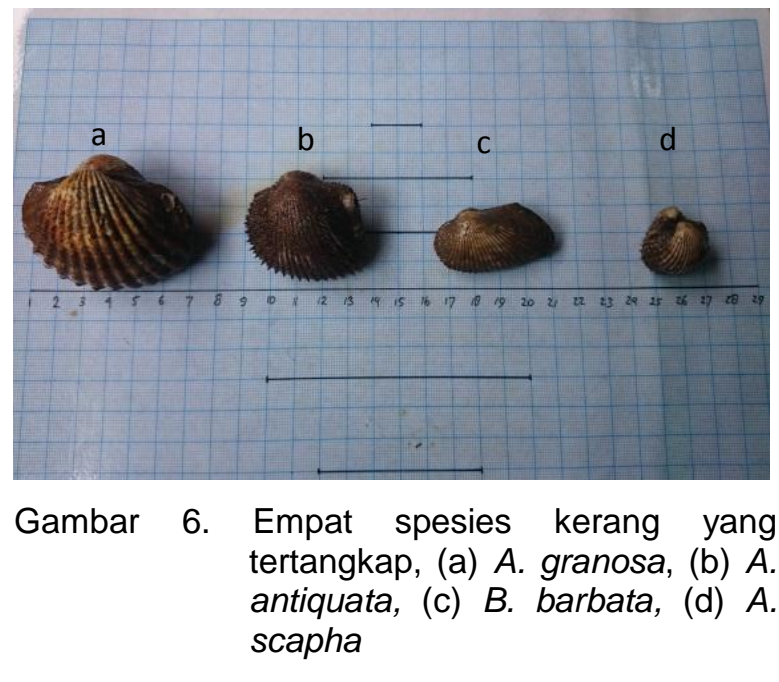

Perbedaan kondisi perairan pada setiap stasiun seperti nilai salinitas dan $\mathrm{pH}$ dikarenakan pengambilan sampel air dilakukan dekat dengan muara sungai dan pengambilan pada saat surut, sehingga air tawar lebih dominan dibandingkan dengan air laut, selain dipengaruhi oleh limpasan air dari perairan teresterial, karena sampling dilakukan pada saat musim penghujan, sehingga 
nilai salinitas dan $\mathrm{pH}$ akan mempengaruhi pertumbuhan organisme disekitar. Adanya kegiatan penambangan pasir dan aktivitas alih fungsi lahan menjadi pabrik dan kegiatan industri akan mempengaruhi kedalaman, sehingga akan berdampak pada pendangkalan dan perbedaan substrat di setiap perairan ${ }^{(16)}$. Di Perairan Karangantu substrat dominan debu lumpur berpasir, sedangkan di Perairan Labuan substrat dominan debu pasir berlumpur. Perbedaan substrat menyebakan sumber makanan untuk hewan bentik berbeda yang berdampak pada potensi sumberdaya kekerangan di setiap lokasi berbeda. Perairan Labuan yang memiliki substrat lumpur berpasir mengindikasikan bahwa perairan tersebut masuk dalam kondisi perairan yang subur, karena banyak terdapat sumber nutrien, sehingga terjadinya siklus rantai makanan dalam perairan tersebut ${ }^{(17)}$. Nilai suhu dan klorin pada dua lokasi perairan yang berbeda masih tergolong baik. Pada lokasi yang dekat dengan PLTU nilai klorin dan suhunya masih stabil, karena pemakaian klorin yang digunakan sebagai pengontrol biological fouling. Klorin adalah oksidan kuat dan dianggap sebagai antibakteri yang sangat efektif karena dapat menghentikan aktivitas enzim dalam sel bakteri secara irreversible. Prinsip kerja klorin adalah oksidasi gugus sulphydryl group terutama pada enzim-enzim esensial sehingga mematikan sel $^{(18)}$.

Berbagai industri yang menggunakan klorin dalam proses kegiatannya akan menghasilkan limbah yang mengandung klorin. Limbah tersebut dapat berbentuk padat, cair maupun gas. Industri yang menggunakan klorin antara lain industri plastik, pelarut semen, pulp dan kertas, pestisida, metal, pembangkit listrik dan industri kimia lainnya. Limbah yang mengandung klorin tersebut dapat mencemari lingkungan apabila tidak dilakukan pengolahan sebelum dibuang ke lingkungan. Sifat klorin yang sangat reaktif akan sangat mudah bagi klorin bereaksi dengan senyawa lain dan membentuk senyawa-senyawa baru seperti senyawa organoklorin yang merupakan senyawa toksik dan dapat menimbulkan efek karsinogen bagi manusia( ${ }^{(19)}$. Menurut $^{(20)}$, konsentrasi klorin sebesar 0,2-0,4 dapat mengganggu indra pembau pada manusia dalam beberapa waktu, sedangkan ada beberapa biota air yang dapat mentoleransi keberadaan klorin dalam bentuk lain seperti hipoklorit di dalam medium kultur in vitro.

\section{KESIMPULAN}

Potensi sumberdaya kekerangan di Perairan Karangantu yaitu $A$. granosa dan $A$. antiquata, sedangkan di Perairan Labuan yaitu $A$. granosa, $A$. scapha dan $B$. barbata. Perbedaan lingkungan perairan mempengaruhi ukuran morfologi kerang. Spesies $A$. granosa di Perairan Labuan memiliki ukuran cangkang yang lebih besar di bandingkan dengan Perairan Labuan dan $A$. granosa merupakan spesies kerang yang memiliki daya tahan dan potensi dari sepanjang Teluk Banten sampai dengan Teluk Lada. Setiap spesies memiliki morfologi yang berbeda-beda. Morfologi A. granosa bercangkang kasar dan besar membulat dan tidak berambut, $A$. scapha bercangkang halus dan kecil membulat dan berambut tipis, $B$. barbata bercangkang halus dan kecil memanjang dan berambut, $A$. antiquata bercangkang halus dan besar membulat dan berambut tebal.

\section{PERSANTUNAN}

Ucapan terima kasih penulis sampaikan kepada Departemen Manajemen Sumberdaya Perairan IPB yang telah mendukung persiapan penelitian ini.

\section{DAFTAR PUSTAKA}

1. Komala, R., F. Yulianda, D.T.F. Lumbanbatu, dan I. Setyobudiandi, (2011), Morfometrik Kerang Anadara granosa dan Anadara antiquata pada Wilayah yang Terekploitasi di Teluk Lada Perairan Selat Sunda, Jurnal IImiah Pertanian - UMMI, 1(1): $14-18$.

2. Zahiruddin, W., (1996), Pengaruh Pemanasan Terhadap Perubahan Flora Bakteri Pada Kerang Darah (Anadara granosa), Buletin Teknologi Hasil Perikanan, Institut Pertanian Bogor, 2(1): 50-53.

3. Nurdin, J., N. Marusin, I.A. Asmara, R. Deswandi, dan I. Marzuki, (2006), Kepadatan Populasi dan Pertumbuhan Kerang Darah Anadara antiquata L. (Bivalvia: Arcidae) di Teluk Sungai Pisang, Kota Padang, Sumatera Barat, Makara Sains, 10(2): 96-101.

4. Tang, U.M., P. Rengi, D. Erianto, dan Sumarto, (2009), Budidaya Kerang (Anadara granosa) di Bengkalis Riau, Prosiding Seminar Nasional Moluska 2, Institut Pertanian Bogor.

5. Setyobudiandi, I., (2004), Beberapa Aspek Biologi Reproduksi Kerang Hijau Perna viridis Linnaeus, 1758 pada kondisi perairan berbeda, Disertasi, Sekolah Pascasarjana, IPB., Bogor. p. 169.

6. Hendarti, N., H. Siegel, and T. Ohde, (2004), Investigation of Different Coastal Processes in Indonesia Waters Using Sea WiFS Data, Deer Sea Res, 51(2):85-97. 
7. Hall, N.G., K.D. Smith, S. de Lestang, and I.C. Potter, (2006), Does the Largest Chela of the Males of Three Crab Species Undergo an Allometric Change that can be used to Determine Morphometric Maturity, ICES J., Makara. Sains, 63 (1): 140-150.

8. Abbot, R.T., and S.P. Dance, (1998), A Full-Color Guide to More Than 4,200 of the World's Marine Shells, Compendium of Seashells, Odyssey Publishing, p. 411.

9. Anonim, (2012), Standard Methods for The Examination of Water and Waste Water $\left(22^{\text {th }}\right.$ Ed.), APHA., AWWA., WPOF., Washington DC.

10. Smith, K.M.M., (1996), Length-Weight Relationships of Fishes in a Diverse Tropical Freshwater Community, Sabah, Malaysia, Journal of Fish Biology, 46:731734.

11. Walpole, R.E., (1992), Pengantar Statistika. Jakarta: Gramedia Pustaka Utama, 515p.

12. Nurjanah, Zulhamsyah, dan Kustiyariyah, (2005), Kandungan Mineral dan Proksimat Kerang Darah (Anadara granosa) yang Diambil dari Kabupaten Boalemo, Gorontalo, Buletin Teknologi Hasil Perikanan, Institut Pertanian Bogor, 8(2):15-24.

13. Butet, N.A., (2013), Plastisitas Fenotip Kerang Darah Anadara granosa L. dalam Merespon Pencemaran Lingkunga: Studi Kasus di Perairan Pesisir Banten, Disertasi, Sekolah Pascasarjana, IPB, Bogor. p. 92.

14. Suwarni, (2009), Hubungan Panjang-Bobot dan Faktor Kondisi Ikan Butana Acanthurus mata (Cuvier, 1892) yang Tertangkap di Sekitar Perairan Pantai Desa Mattiro Deceng, Kabupaten Pangkajene Kepulauan, Provinsi Sulawesi Selatan, Torani, Jurnal Ilmu Kelautan dan Perikanan, 19(3):160-165.
15. Wahyudewantoro, G., (2013), Hubungan Panjang Berat dan Faktor Kondisi Ikan Belanak Liza subviridis di Perairan Taman Nasional Ujung Kulon-Pandeglang, Banten, Bionatura, Jurnal IImu-ilmu Hayati dan Fisik, 15(3):192-195

16. Yennie, Y., dan J.T. Murtini, (2005), Kandungan Logam Berat Air Laut, Sedimen dan Daging Kerang Darah (Anadara granosa) di Perairan Mentok dan Tanjung Jabung Timur, Jurnal Ilmu-ilmu Perairan dan Perikanan, 12(1):27-32.

17. Riniatsih, I., dan Widianingsih, (2007), Kelimpahan dan Pola Sebaran Kerangkerangan (Bivalve) di Ekosistem Padang Lamun, Perairan Jepara, Jurnal IImu Kelautan, 12(1):53-58.

18. Armansyah, H., Y. Linggi, Maheno, dan Marsoedi, (2014), Kemampuan Oosit Ikan Lele (Clarias grapienus) dalam Menoleransi Klorin sebagai Bahan Oksidatif Stres, Jurnal Kedokteran Hewan, 8(1): 43-47.

19. Hasan, A., (2006), Dampak Penggunaan Klorin, Journal Teknologi Lingkungan, 7(1):90-96.

20. Rosyidi, M.B., (2010), Pengaruh Breakpoint Chlorination (BPC) terhadap Jumlah Bakteri Koliform dari Limbah Cair Rumah Sakit Umum Daerah Sidoarjo, Makara Sains, Kesehatan, 9(1):23-28. 